\section{THE DUST HAZARD IN CERTAIN INDUSTRIES *}

T. GRIER MILLER, M.D.

Physician-in-Chief, Clinic for Diseases of Occupation AND

HENRY FIELD SMYTH, M.D., DR.P.H.

Acting Director, Laboratory of Hygiene; Hygienist, Clinic for Diseases of Occupation

PHILADELPHIA

No health hazard in industry has attracted so much attention, and rightly so, as dust, and yet few exact studies on its nature and quantitative features have appeared. It is not enough to know only that dust has an influence on health, or even what the resultant pathologic conditions are; it must also be shown how these effects are brought about. In order to approach this problem intelligently, it is of prime importance to appreciate certain things about dust itself, and in this communication are presented briefly the results of investigations on the dusts of various industries. These show the number of particles per unit volume of air and their approximate size, the weight and relative mineral content, the influence of relative atmospheric humidity and of exhaust ventilation on these factors, and the amount that reaches the lungs of those exposed.

The dust samples have been collected directly from the air, at the respiration level, by means of the Palmer apparatus, ${ }^{1}$ which is now accepted as a standard by the American Public Health Association, and the determinations have been made by the methods of Palmer, Coleman, and Ward, ${ }^{2}$ as modified by Smyth. ${ }^{3}$ The chief advantages of this apparatus are that it allows a very large volume

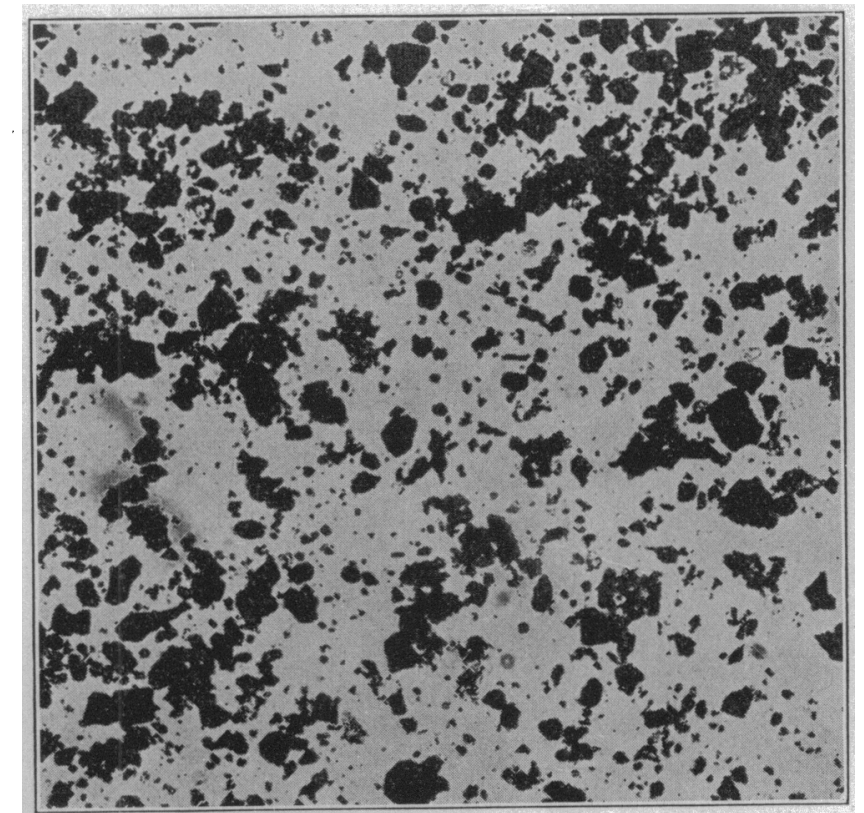

Fig. 1-Dust collected from the air of the coal grinding room of a cement plant; $X$ 100; appearance after settling in a Sedgwick-Rafter cell: obtained by passing 50 cubic feet of the air through 100 c.c. of distilled water.
STANDARD DUST VALUES FOR PHILADELPHIA

In order to have, as standards, certain dust values with which our results in the industries might be com-

TABLE 1.-RESULTS FROM THE EXAMINATION OF DUST IN COUNTRY AND CITY AIR

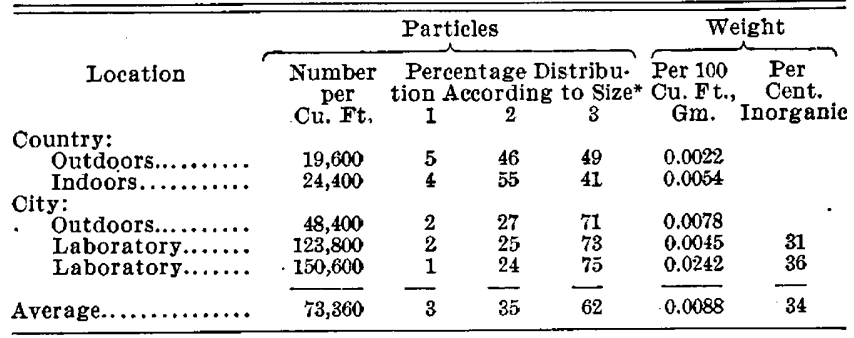

* In this and the succeeding tables, size 1 refers to the largest observed particles, averaging about 40 microns in diameter, Size 3 to the smallest ones, averaging about 1 micron, and Size 2 to the intermediates.

pared, five tests were made outside such establishments, as follows: one each in the country and the city outdoors, one in a country home, and two in city laboratories. Table 1 gives the results of these tests, with averages, and these we have accepted as normal values for Philadelphia and its vicinity. Outdoor country air, the most dust-free examined, showed under 20,000 particles per cubic foot with $2.2 \mathrm{mg}$. of solids in each hundred cubic feet, and indoor country air under 25,000 particles with 5.4 mg. of solids. Outdoor city air contained about twice as many particles as the latter, with $7.8 \mathrm{mg}$. of solids, and the laboratory air averaged about six times as many particles with three times the weight. A striking difference is seen in the relative proportion of small and large particles when comparing city with country air, the latter containing relatively fewer of the smallest countable ones. The somewhat low percentage of inorganic material in the laboratory dust resulted partly from an abundance of coal particles which came from a near-by freight railroad and a large power plant stack.

\section{INORGANIC DUSTS}

Portland Cement.-In Table 2 are given the results of tests on eleven dust samples from three Portland cement plants situated in the Lehigh Valley of Eastern Pennsylvania. These are averaged as a whole and also by the presence or absence of exhaust ventilation, departments $33 \mathrm{c}, 34 \mathrm{c}$, and $38 \mathrm{r}$ having such ventilation by means of stacks over the conveyors. No other industry gave results so high in either count or weight, the average being almost 7 million particles per cubic foot and over $0.2 \mathrm{gm}$. of solids in 100 cubic feet. The number of particles in three tests was appalling, two running over 13 million and one over 15 million, and 
the lowest count in any of the cement departments was $11 / 4$ million. The highest weights were 0.4928 and

TABLE 2.-RESULTS FROM THE EXAMINATION OF DUSTS IN THE CEMENT INDUSTRY

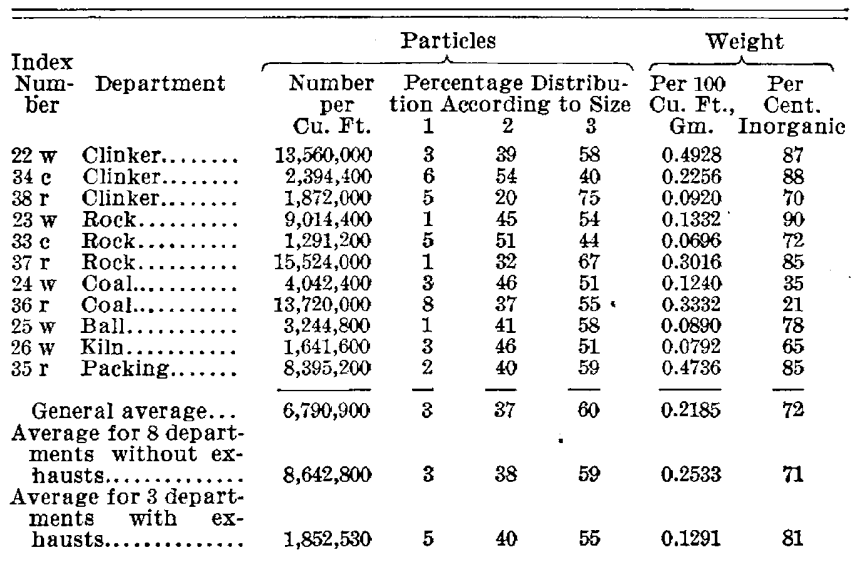

$0.4736 \mathrm{gm}$. The ratio of small to large particles was between the extremes of country and city air. A comparison of the number of particles with the weights in Departments $35 \mathrm{r}, 36 \mathrm{r}$ and $37 \mathrm{r}$ shows that while the numbers increase the weights decrease. This is due to a difference in the specific gravity of the dusts and to differences in the sizes of the particles. The percentage of inorganic mat. ter varied from 21 to 90 , the dust from the coal grinding room showing the lowest. The averages for the departments with and without exhaust ventilation show clearly that such exhausts effect both a great reduction in the number of particles and in the weight, and also a slight reduction in the percentage of the smallest sized particles.

TABLE 3.-RESULTS FROM THE EXAMINATION OF DUSTS IN THE FLINT INDUSTRY

\begin{tabular}{|c|c|c|c|c|c|c|c|}
\hline \multirow{2}{*}{$\begin{array}{l}\text { Index } \\
\text { Num- } \\
\text { ber }\end{array}$} & \multirow[b]{2}{*}{ Department } & \multicolumn{4}{|c|}{ Particles } & \multicolumn{2}{|c|}{ Weight } \\
\hline & & $\begin{array}{c}\text { Number } \\
\text { per } \\
\text { Cu. Ft. }\end{array}$ & $\begin{array}{c}\text { Perc } \\
\text { tion } \\
1\end{array}$ & $\begin{array}{l}\text { tage } \\
\text { ordi } \\
\quad 2\end{array}$ & $\begin{array}{c}\text { Distribu- } \\
\text { ing to Size } \\
\mathbf{3}\end{array}$ & $\begin{array}{l}\text { Per } 100 \\
\text { Cu. Ft., } \\
\text { Gm. }\end{array}$ & 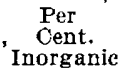 \\
\hline $\begin{array}{l}54 \mathrm{e} \\
55 \mathrm{e} \\
56 \mathrm{~g}\end{array}$ & $\begin{array}{l}\text { Ball grinding... } \\
\text { Crushing....... } \\
\text { Ball grinding... }\end{array}$ & $\begin{array}{r}582,400 \\
937,600 \\
1,120,100\end{array}$ & $\begin{array}{l}\mathbf{5} \\
\mathbf{3} \\
\mathbf{4}\end{array}$ & $\begin{array}{l}31 \\
26 \\
36\end{array}$ & $\begin{array}{l}64 \\
71 \\
66\end{array}$ & $\begin{array}{l}0.0384 \\
0.0464 \\
0.0336\end{array}$ & $\begin{array}{l}67 \\
86 \\
76\end{array}$ \\
\hline \multicolumn{2}{|c|}{ Average............ } & 844,040 & 4 & 31 & 65 & 0.0459 & 76 \\
\hline
\end{tabular}

Flint.-Three tests were made in two flint mills $($ Table-3). Unfortunately, the sampling in one mill ( $54 \mathrm{e}$ and $55 \mathrm{e}$ ) was rather unsatisfactory because of a defective electric current, and the results should probably have been slightly higher than here recorded. In this plant the crushing, which was not protected, generated more dust than the ball grinding, and incidentally the man feeding the crusher was continually exposed. In the other flint establishment $(56 \mathrm{~g})$ the crushing mills were enclosed and supposedly protected by strong exhaust suction, but, as sometimes happens,

TABLE 4.-RESULTS FROM THE EXAMINATION OF DUSTS IN THE STEEL GRINDING INDUSTRY

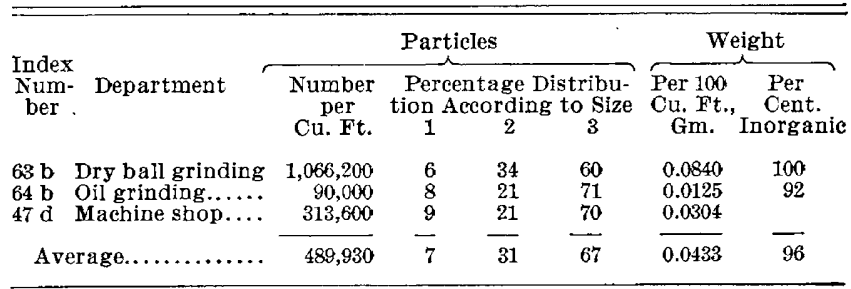

the suction was not detectable, owing to loosened boards in the upper part of the enclosure. The ball grinding drums were enclosed at both mills, as they. should be. This dust showed a high percentage of Size 3 particles.

Steel Grinding.-.-Samples of dust from the emery grinding of steel were taken in a machine shop of a textile mill and in a ball bearing factory, and the results are recorded in Table. 4 . The most striking fact is the great difference in the figures for the two departments of the ball bearing factory: in the dry grinding department (63 b), where the horizontal emery wheels throw countless particles in every direction and where incidentally the workers have no protection whatever, the figures are high, while in the oil grinding room (64 b), where the process is the same except that the balls run in oil, the 
ing illustration of the value of wet processes. The dry ball grinding is the only department of the entire series showing dust composed entirely of mineral matter.

TABLE 6.-RESULTS FROM THE EXAMINATION OF DUSTS IN THE POTTERY INDUSTRY

\begin{tabular}{|c|c|c|c|c|c|c|c|}
\hline \multirow{2}{*}{$\begin{array}{l}\text { Index } \\
\text { Num- } \\
\text { ber }\end{array}$} & \multirow[b]{2}{*}{ Department } & \multicolumn{4}{|c|}{ Particles } & \multicolumn{2}{|c|}{ Weight } \\
\hline & & $\begin{array}{c}\text { Number } \\
\text { per } \\
\text { Cu. Ft. }\end{array}$ & $\begin{array}{c}\text { Perce } \\
\text { tion A } \\
1\end{array}$ & $\begin{array}{l}\text { ge } \\
\text { rdi }\end{array}$ & $\begin{array}{c}\text { Distribu- } \\
\text { ag to Size } \\
3\end{array}$ & $\begin{array}{l}\text { Per } 100 \\
\text { Cu. Ft., } \\
\text { Gm. }\end{array}$ & $\begin{array}{c}\text { Per } \\
\text { Cent. } \\
\text { Inorganie }\end{array}$ \\
\hline $\begin{array}{l}491 \\
501 \\
511 \\
52 \mathrm{~m} \\
53 \mathrm{e}\end{array}$ & $\begin{array}{l}\text { Glaze dipping.. } \\
\text { Jiggering....... } \\
\text { Kiln............ } \\
\text { Pressing........ } \\
\text { Pressing........ }\end{array}$ & $\begin{array}{l}152,800 \\
189,600 \\
249,600 \\
163,200 \\
158,400\end{array}$ & $\begin{array}{l}8 \\
4 \\
4 \\
4 \\
4\end{array}$ & $\begin{array}{l}41 \\
33 \\
33 \\
28 \\
33\end{array}$ & $\begin{array}{l}51 \\
63 \\
63 \\
68 \\
63\end{array}$ & $\begin{array}{l}0.0144 \\
0.0120 \\
0.0200 \\
0.0072 \\
0.0084\end{array}$ & $\begin{array}{l}38 \\
67 \\
64 \\
67 \\
71\end{array}$ \\
\hline \multicolumn{2}{|c|}{ Average.. } & 182,720 & 5 & 34 & 61 & 0.0130 & 60 \\
\hline
\end{tabular}

Asbestos.-Table 5 records the results of six tests in two asbestos fiber weaving mills, the second of which had almost completed the installation of an exhaust system for dust removal. The averages in these two mills show clearly the effect of such dust removal, not only in lessening the number of particles and the weight of the dust, but also in decreasing the percentage of the smallest sized particles.

Crushing is seen to be the dustiest process, and it is also the most diffcult to guard properly. The crushing room that did not have a suction system ( 59 a), with over 1 million particles per cubic foot, ranked next to the cement departments in dustiness, and above any of the steel or flint departments, and the carding room in the same mill (58 a) was not far behind. The percentage of inorganic matter in this dust varied from 31 to 82 .

Potteries.-Table 6 gives the results of five dust tests in three potteries located in Trenton, N. J. These are the lowest figures shown by any of the inorganic industries, the highest count being under 300,000 . The latter (511) was in a kiln room where tableware was being packed in saggers with powdered flint, and this packing was done in especially constructed boxes with strong exhaust suction at the rear. With the exception of this one department, there was very little variation in the counts in this industry, though there was considerable difference in the weights. The relatively high weight, in proportion to the count, in the glaze dipping room was due to 8.6 per cent. of lead in this dust, a somewhat lower percentage than in the glaze itself. Calculations show that the workers here inhale at most under $2 \mathrm{mg}$. of lead a day. The percentage of smallest particles here was somewhat less than in the flint mill tests.

ORGANIC DUSTS

Plush, Blanket and Carpet.-Thirteen tests were made in three divisions of a large textile mill making silk and mohair plush, woolen blankets, aeroplane wing cloth, and carpets (Table 7 ). The wool breaking room (33 d) in the carpet factory showed by far the worst organic dust conditions encountered, with 430,000 particles, little less than in the best flint mill test, and with $0.39 \mathrm{gm}$. of solids, exceeded only by the three highest tests in cement. It so happens also that this dust is peculiarly harmful, because as the raw, unwashed wool is fed to the breaker, much of the dirt from it is blown directly back into the face of the feeder. Another equally harmful dust tested in this mill, which gave a lower count and weight but a decidedly higher percentage of mineral matter, was that in the rag picking room ( $43 \mathrm{~d})$, where filthy woolen rags of all descriptions are fed by hand into a shredding machine. The shredded material is blown into a supposedly closed room, but the door is left open, allowing the fine shreds and dust to escape into the main room; and furthermore, at intervals, the operative enters the enclosure and brings out the material by the double armful to bale on the open floor. In so doing he is exposed to much more dust than the results of the test, taken near his station when he is feeding the machine, would indicate. In general, plush mill dusts gave higher counts than carpet mill dusts, but one weaving room ( 29 d) gave a very low test (under 77,000 particles), little more than one third of the count in the other plush weaving room. Tests in the blanket mill gave remarkably low counts, owing to greater cleanliness and also to the use of wet processes, the bobbins being loaded with steamed thread. Thus again is seen the value of wet processes. All tests in these three mills showed more or less mineral matter in the so-called organic dust, from 17 per cent. in the wool breaking ( $33 \mathrm{~d}$ ) to 68 per cent. in a plush

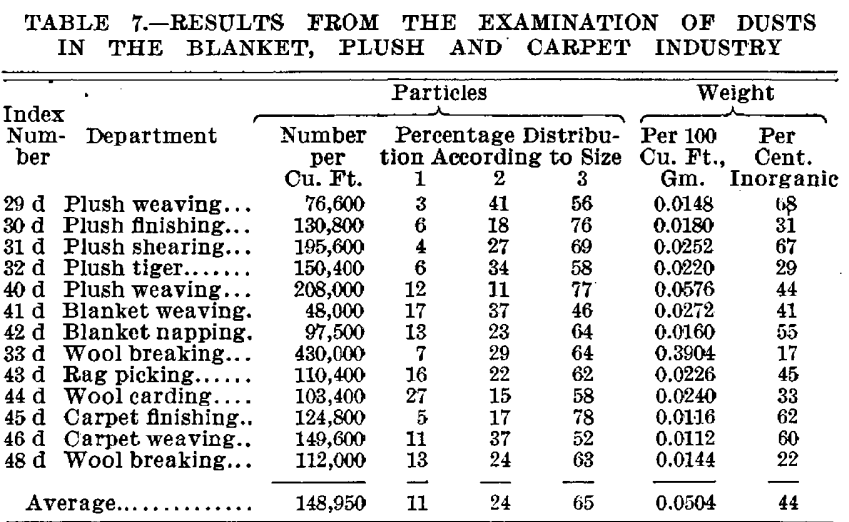

weaving room ( $29 \mathrm{~d}$ ). Some of the mineral matter in the dust from the weaving rooms is no doubt due to the wear and tear of the machinery. 
Felt Hat.-Only three tests in a hat factory were made, all in departments handling unfelted fur (Table 8). They show fair conditions, with no very high

\begin{tabular}{|c|c|c|c|c|c|c|c|}
\hline \multirow[b]{2}{*}{$\begin{array}{l}\text { Index } \\
\text { Num- } \\
\text { ber }\end{array}$} & \multirow[b]{2}{*}{ Department } & \multicolumn{4}{|c|}{ Particles } & \multicolumn{2}{|c|}{ Weight } \\
\hline & & $\begin{array}{l}\text { Number } \\
\text { per } \\
\text { Cu. Ft. }\end{array}$ & $\begin{array}{c}\text { Perc } \\
\text { tion } \\
1\end{array}$ & $\begin{array}{c}\text { centage } \\
\text { Accord! } \\
2\end{array}$ & $\begin{array}{l}\text { Pstribu- } \\
\text { Ing to Size } \\
3\end{array}$ & $\begin{array}{l}\text { Per 100 } \\
\text { Ou. Ft., } \\
\text { Gm. }\end{array}$ & $\begin{array}{c}\text { Per } \\
\text { Cent. } \\
\text { Inorganic }\end{array}$ \\
\hline $\begin{array}{l}60 \mathrm{~s} \\
61 \mathrm{~s} \\
62 \mathrm{~s}\end{array}$ & $\begin{array}{l}\text { Fur eutting.... } \\
\text { Fur blowing.... } \\
\text { Forming....... }\end{array}$ & $\begin{array}{r}153,100 \\
133,600 \\
81,360\end{array}$ & $\begin{array}{l}2 \\
8 \\
3\end{array}$ & $\begin{array}{l}28 \\
32 \\
42\end{array}$ & $\begin{array}{l}70 \\
60 \\
55\end{array}$ & $\begin{array}{l}0.0160 \\
0.0176\end{array}$ & $\begin{array}{l}30 \\
48\end{array}$ \\
\hline $\begin{array}{r}\text { Aver } \\
\text { de }\end{array}$ & $\begin{array}{l}\text { rage for the } 3 \\
\text { partments....... }\end{array}$ & 126,020 & 4 & 33 & 63 & 0.0168 & 39 \\
\hline
\end{tabular}

count, and the decreasing percentage of smallest particles shows the effect of brushing and blowing in cleaning the fur before forming. Lower counts in the

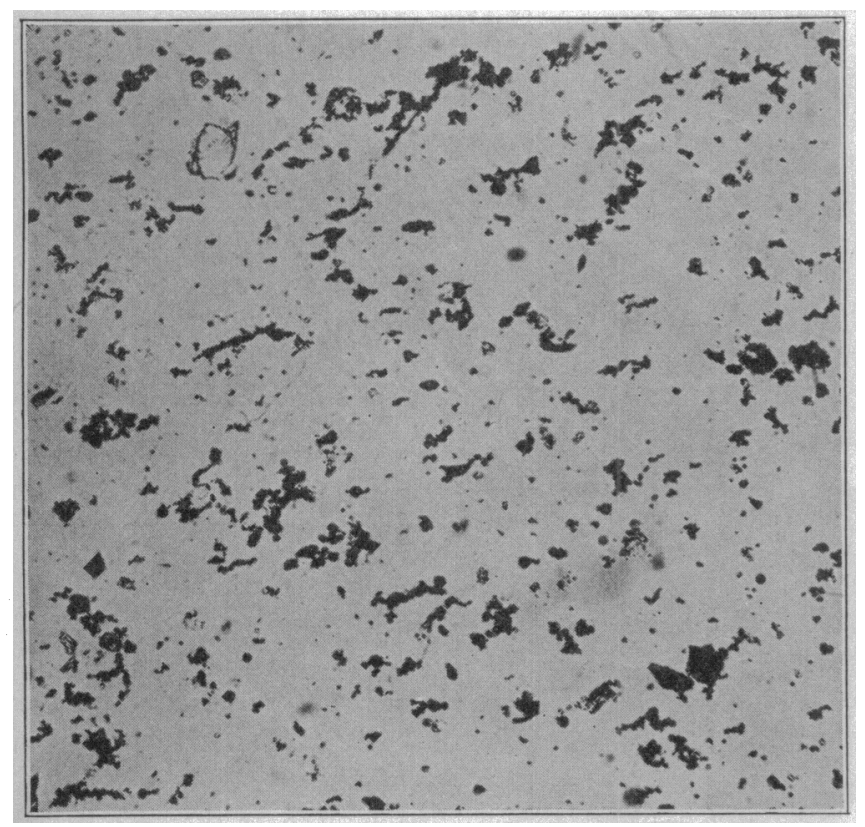

Fig. 4.-Dust from the air of the dry grinding department of a steel ball bearing plant; $X$ 100; appearance in Sedgwick-Rafter cell; the dust of 200 cubic feet of the air suspended in 100 c.c. of distilled water.

brushing and forming departments are doubtless partly due to increased humidity. The highest count is seen in the most dangerous process, fur cutting $(60 \mathrm{~s})$,

TABLE 9.-AVERAGE RESULTS OF DUST EXAMINATIONS IN NINETEEN DEPARTMENTS OF SIX CIGAR FACTORIES

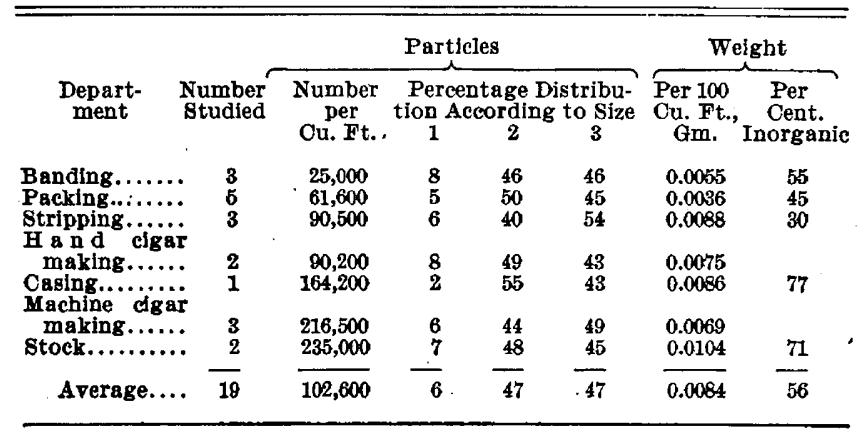

where the fur is full of dried "carrot" (mercury acid nitrate), this being put on to aid in the felting process, and the dust here is liable to cause mercurial poisoning.
Cigar.-The results of our nineteen tests in cigar factories have been reported elsewhere; ${ }^{5}$ hence only the averages in the different departments are given here (Table 9). While in general these tests show comparatively little dust, yet two counts of over 300,000 particles were made, and one test gave a weight of $0.017 \mathrm{gm}$. The somewhat high inorganic content of the dust is doubtless due to sand, which is invariably

TABLE 10.-RESULTS FROM THE EXAMINATION OF DUSTS IN THE SIYK INDUSTRY

\begin{tabular}{|c|c|c|c|c|c|c|c|}
\hline \multirow[b]{2}{*}{$\begin{array}{l}\text { Index } \\
\text { Num- } \\
\text { ber }\end{array}$} & \multirow[b]{2}{*}{ Department } & \multicolumn{4}{|c|}{ Particles } & \multicolumn{2}{|c|}{ Weight } \\
\hline & & $\begin{array}{c}\text { Number } \\
\text { per } \\
\text { Cu. Ft. }\end{array}$ & $\begin{array}{r}\text { Per } \\
\text { tion } \\
1\end{array}$ & $\begin{array}{c}\text { ntage } \\
\text { ceordi } \\
2\end{array}$ & $\begin{array}{l}\text { e Distribu- } \\
\text { ling to Size } \\
\mathbf{3}\end{array}$ & $\begin{array}{l}\text { Per } 100 \\
\text { Cu. Ft., } \\
\text { Gm. }\end{array}$ & $\begin{array}{c}\text { Per } \\
\text { Cent. } \\
\text { Inorganic }\end{array}$ \\
\hline $\begin{array}{l}27 \mathrm{q} \\
28 \mathrm{q}\end{array}$ & $\begin{array}{l}\text { Weaving......... } \\
\text { Winding........ }\end{array}$ & $\begin{array}{r}109,800 \\
64,200\end{array}$ & $\begin{array}{l}15 \\
32\end{array}$ & $\begin{array}{l}2 \\
3\end{array}$ & $\begin{array}{l}83 \\
65\end{array}$ & $\begin{array}{l}0.0040 \\
0.0050\end{array}$ & $\begin{array}{l}60 \\
40\end{array}$ \\
\hline \multicolumn{2}{|c|}{$\begin{array}{c}\text { Average for the } 2 \\
\text { departments...... }\end{array}$} & 87,000 & 23 & 3 & 74 & 0.0045 & 50 \\
\hline
\end{tabular}

associated with tobacco, and to the wear of the machinery.

Silk.-Two tests were made in a model silk factory, and Table 10 shows that these gave results averaging better than in any other industry, and exceeded only by country air and a few individual tests in cigar factories. This was due to extreme cleanliness and to artificially increased humidity. The inorganic content of this dust averaged 50 per cent.

\begin{tabular}{|c|c|c|c|c|c|c|c|}
\hline \multirow[b]{2}{*}{ Industry } & \multirow{2}{*}{$\begin{array}{l}\text { Number } \\
\text { of Tests }\end{array}$} & \multicolumn{4}{|c|}{ Particles } & \multicolumn{2}{|c|}{ Weight } \\
\hline & & $\begin{array}{c}\text { per } \\
\text { Cu. Ft. }\end{array}$ & $\begin{array}{r}\text { tion } \\
1\end{array}$ & $\underset{2}{\operatorname{cordi}}$ & to Size & $\begin{array}{l}\text { Cu. Ft., } \\
\text { Gm. }\end{array}$ & $\begin{array}{c}\text { Cent. } \\
\text { Inorganic }\end{array}$ \\
\hline Cement.... & & $6,790,900$ & 3 & 37 & 60 & 0.2185 & 72 \\
\hline Flint....... & 3 (2) & 844,040 & 4 & 31 & 65 & 0.0459 & 76 \\
\hline Steel....... & 3 (2) & 489,930 & 7 & 31 & 62 & 0.0433 & 96 \\
\hline Asbestos... & $6 \quad(2)$ & 494,100 & 4 & 39 & 57 & 0.0354 & 73 \\
\hline Pottery.... & 5 (3) & 182,720 & 5 & 34 & 61 & 0.0130 & 60 \\
\hline Average.. & 28 (11) & $1,777,970$ & 4 & 37 & 59 & 0.0717 & 76 \\
\hline
\end{tabular}

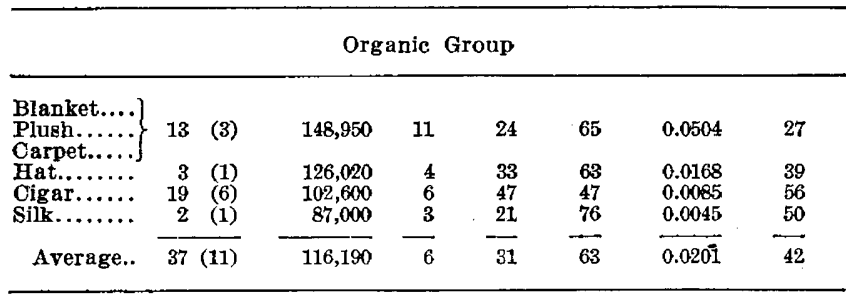

\begin{tabular}{llllllllll}
\hline \multicolumn{10}{c}{ Standard } \\
\hline Average.... & 5 & $(4)$ & 73,360 & 3 & 35 & 62 & 0.0088 & 34 \\
\hline
\end{tabular}

\section{SUMMARY OF AVERAGES}

Table 11 gives a general summary of the averages for the several industries, grouped according to the organic or inorganic nature of the raw material used. A remarkable uniformity in the percentage of different sized particles in all the tests is observed. It will be seen that the dustiness is much greater in the inorganic class, and that, although the percentage of inorganic material is naturally greater in this group, yet the so-

5. Smyth, H. F., and Miller, T. G.: A Hygienic Survey of Cigar Manufacturing in Philadelphia, Med. and Surgyienic Survey 
called organic dusts show a mineral content averaging 42 per cent.

\section{EFFECT OF HUMIDITY}

In forty instances in which dust tests were made, relative humidity readings were taken at the same time with a sling psychrometer, and Table 12 shows that as

TABLE 12.-EFFECT OF HUMIDITY ON THE SIZE OF DUST PARTICLES

\begin{tabular}{|c|c|c|c|c|}
\hline \multirow{2}{*}{$\begin{array}{c}\text { Relative } \\
\text { Humidity }\end{array}$} & \multirow{2}{*}{$\underset{\text { Tests }}{\text { Number of }}$} & \multicolumn{3}{|c|}{$\begin{array}{c}\text { Percentage Distribution of } \\
\text { Particles by Size }\end{array}$} \\
\hline & & 1 & 2 & 3 \\
\hline $\begin{array}{l}\text { From } 35 \text { to } 39 \ldots \ldots \ldots \ldots \\
\text { From } 40 \text { to } 49 \ldots \ldots \ldots \ldots \\
\text { From } 50 \text { to } 59 \ldots \ldots \ldots \ldots \\
\text { From } 60 \text { to } 69 \ldots \ldots \ldots \ldots \\
\text { As humidity increases.. }\end{array}$ & $\begin{array}{r}4 \\
15 \\
11 \\
8 \\
\cdots\end{array}$ & $\begin{array}{c}7 \\
8 \\
6 \\
5 \\
\text { Decreases }\end{array}$ & $\begin{array}{c}36 \\
36 \\
34 \\
33 \\
\text { Decreases }\end{array}$ & $\begin{array}{c}57 \\
56 \\
60 \\
62 \\
\text { Increases }\end{array}$ \\
\hline
\end{tabular}

the humidity increases the percentage of the larger particles decreases, the minute ones correspondingly increasing. Table 13 shows the effect of increases in humidity in individual industries, indicating, in general,

TABLE 13.-EFFECT OF INCREASES IN HUMIDITY ON THE TOTAL DUST COUN'T IN SEPARATE INDUSTRIES

\begin{tabular}{|c|c|c|}
\hline 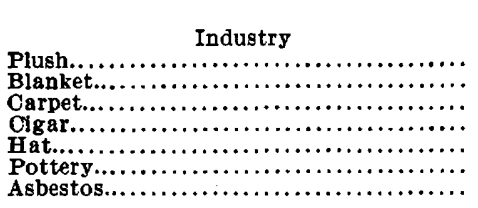 & $\begin{array}{c}\text { Number of } \\
\text { Tests } \\
\mathbf{5} \\
\mathbf{2} \\
\mathbf{4} \\
9 \\
\mathbf{3} \\
\mathbf{4} \\
6\end{array}$ & $\begin{array}{c}\text { Effect on Total } \\
\text { Count } \\
\text { Irregular } \\
\text { Decreased } \\
\text { Irregular } \\
\text { Decreased } \\
\text { Irregular } \\
\text { Decreased } \\
\text { Decreased }\end{array}$ \\
\hline
\end{tabular}

a tendency to lessening of the total dust count. This is naturally more marked with the more hygroscopic dusts.

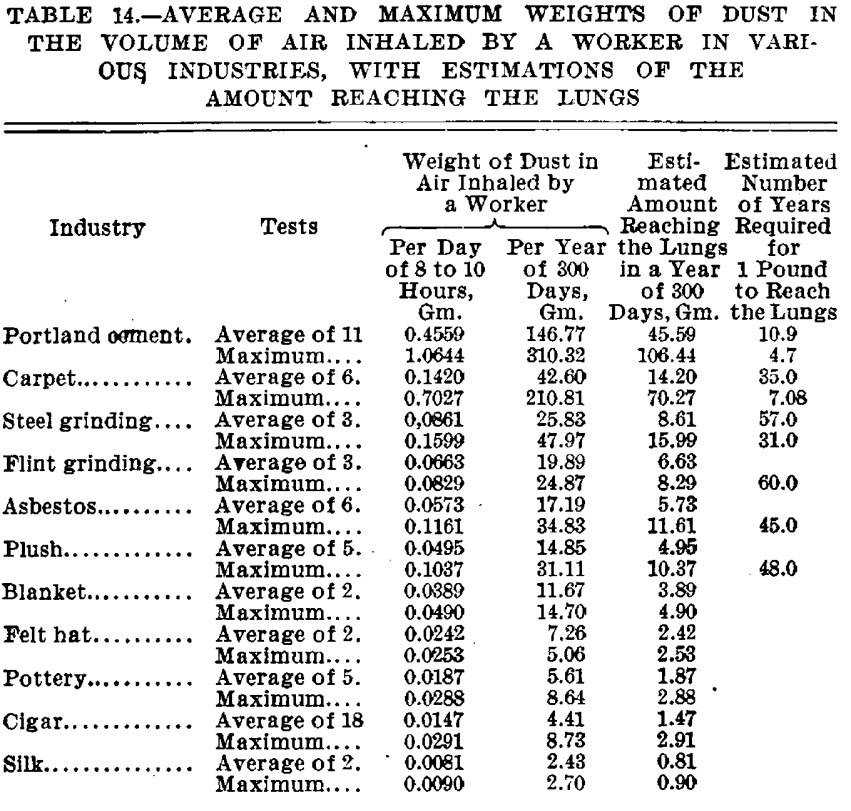

\section{WEIGHT OF DUST INHALED AND REACHING} THE LUNGS

From our data, calculations were made of the amount of dust in the air inhaled by the various workers in a day. These estimates were based on the assumption of 30 inches of tidal air per respiration, and of 18 respirations per minute, this giving approximately 18 cubic feet per hour. From these results, further estimations were made of the amount of dust contained in the air inhaled per working year of 300 days, and of the amount that would reach the lungs. Lehmann and his co-workers ${ }^{6}$ found that from 35 to 42 per cent. of inhaled white lead dust reached the lungs, and so we figured on at least one third of the various inhaled dusts gaining entrance. Table 14 gives our calculations based on the average and the maximum tests in each industry, and in a few instances records the time that would be required for 1 pound of dust to reach the lungs. Table 15 gives corresponding results for city and country air. From the former table it will be seen that the average cement worker inhales almost a half gram of dust a day, and that over $45 \mathrm{gm}$. reach the lungs each year, less than eleven years being required for 1 pound to gain entrance. A worker in the dustiest room inhales over $100 \mathrm{gm}$. a year, and takes in 1 pound in less than five years. The average carpet mill worker inhales $0.142 \mathrm{gm}$.

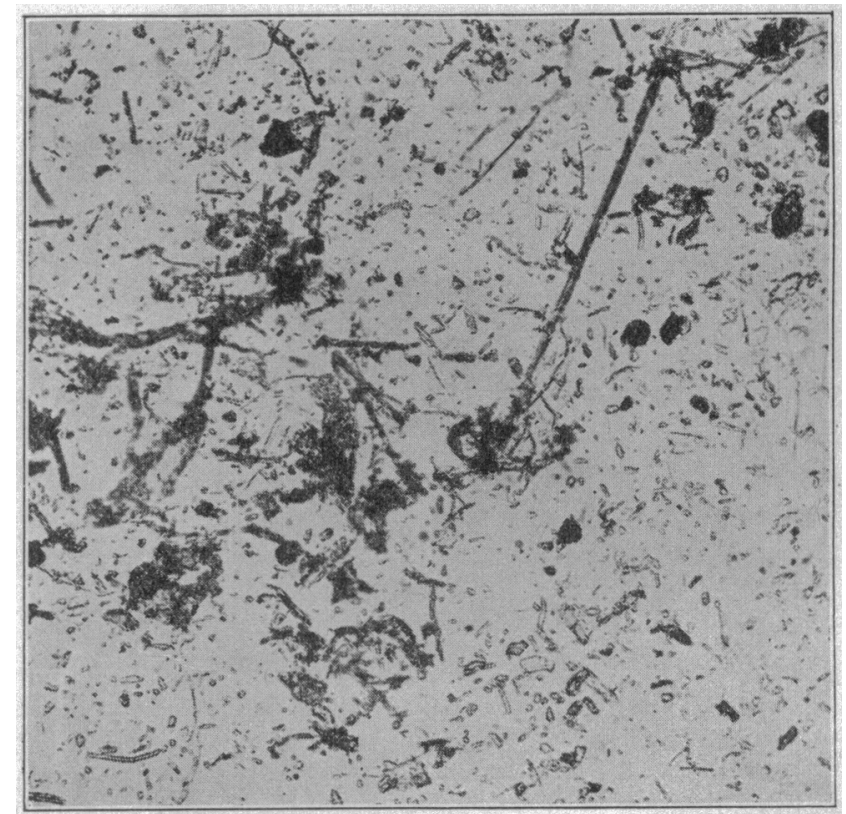

Fig. 5.-Dust collected from the air of an asbestos factory; $\times 100$ appearance in Sedgwick-Rafter cell; the dust of 150 cubic feet of air suspended in 100 c.c. of distilled water.

daily, but the feeder of the wool breaker takes in over $0.7 \mathrm{gm}$., and the latter would receive a pound in a little over seven years. The steel ball bearing grinder

TABLE 15.-AVERAGE AND MAXIMUM WEIGHTS OF DUST IN THE VOLUME OF AIR INHALED BY AN INDIVIDUAL OUT. DOORS AND INDOORS IN PHILADELPHIA, WITH ESTIMATIONS OF THE AMOUNT REAOHING THE LUNGS

\begin{tabular}{|c|c|c|c|c|c|}
\hline \multirow{2}{*}{ Location } & \multirow{2}{*}{ Tests } & \multicolumn{2}{|c|}{$\begin{array}{l}\text { Weight of Dust in } \\
\text { Air Inhaled by } \\
\text { an Individual }\end{array}$} & \multirow{2}{*}{$\begin{array}{c}\text { Esti- } \\
\text { mated } \\
\text { Amount } \\
\text { Reaching } \\
\text { the Lungs } \\
\text { in a Year } \\
\text { of } 365 \\
\text { Days, Gm. }\end{array}$} & $\begin{array}{l}\text { Estimated } \\
\text { Number } \\
\text { of Years } \\
\text { Required } \\
\text { for }\end{array}$ \\
\hline & & $\begin{array}{c}\text { Per Day } \\
\text { of } 24 \\
\text { Hours, } \\
\text { Gm. }\end{array}$ & $\begin{array}{c}\text { Per Year } \\
\text { of } 365 \\
\text { Days } \\
\text { Gm. }\end{array}$ & & $\begin{array}{l}\text { foquired } \\
\text { for } \\
1 \text { Pound } \\
\text { to Reach } \\
\text { the Lungs }\end{array}$ \\
\hline Indoors. & Average of 3. . & 0.0492 & 17.96 & 4.92 & 100.0 \\
\hline & $\begin{array}{l}\text { Maximum...... } \\
\text { Average of } 2 . .\end{array}$ & $\begin{array}{l}0.1045 \\
0.0299\end{array}$ & & $\begin{array}{r}10.45 \\
2.99\end{array}$ & 48.0 \\
\hline & Maximum & 0.0503 & 15.09 & 5.03 & 99.0 \\
\hline
\end{tabular}

would take thirty-one years to secure a pound, and in none of the other of these industries would so much

6. Lehmann, K. B.; Saito, Y., and Gfrörer, Walter: Ueber die quantitative Absorption von Staub aus der Luft durch den Menschen, Arch. f. Hyg., 1911.1912, 57, 152 . 
be taken in during the average working life of an employee. These amounts would be much increased, however, in workers with any form of nasal obstruction, since Lehmann found that in mouth breathing 80 per cent. of inhaled dust reached the lungs. Arens ${ }^{4}$ calculated that a cement worker would inhale $1.12 \mathrm{gm}$. of dust a day, a foundryman $0.14 \mathrm{gm}$., a wool worker $0.1 \mathrm{gm}$. and a schoolboy $0.0024 \mathrm{gm}$., these figures comparing fairly well with those here reported.

\section{VARIATIONS IN DUSTINESS}

These tests cannot show all the variations that are likely to occur in dust production; but in any study of the dust problem this factor must not be overlooked entirely. Some of our impressions will therefore be recorded. In the dustiest industry included in our survey, cement manufacture, no appreciable variations were suspected except in the packing department. In the flint mills the production was constant in the crushing department, but in the ball grinding department it was greatly increased when the cylinders were charged or emptied; at no time, however, was the air even comparatively free from dust. In the asbestos mills, no appreciable variations were probable. In the pottery kiln room, dust was an appreciable factor only when saggers were being packed or emptied. Elsewhere in the potteries, conditions were more uniform. In the machine shop and the ball bearing grinding room, there were intervals of comparative quiet and of a decrease in dustiness around each machine. Much more variation in dust production occurred in the textile mills and other factories producing organic dusts.

\section{CONCLUSIONS}

A study of dust samples taken directly from the air. at the respiration level, of sixty-five departments of twenty-two plants, representing five industries dealing with inorganic and four with organic materials, has given rise to the following conclusions:

1. For a complete understanding of the problem of dust in industry, there must be considered not only its weight, but also the number of the particles, their nature, whether organic or inorganic, and their percentage distribution according to size.

2. The order of the industries studied in regard to dustiness, as determined by weight, was (1) Portland cement ; (2) plush, carpet and blanket; (3) flint grinding; (4) steel grinding; (5) asbestos; (6) felt hat; (7) pottery; (8) cigar, and (9) silk.

3 . The order as determined by the count of particles was the same except that (1) the asbestos, (2) the plush, carpet and blanket, and (3) the felt hat industries were given lower positions; this was largely due to the presence of fibers in these dusts which it was impossible to include in our counts.

4. The so-called organic dusts were invariably composed of both organic and inorganic materials, and the latter ingredient may account for the harmful influences which have been attributed to certain of these dusts.

5. The organic dusts averaged less than the inorganic dusts both in weight and in count of particles.

6. The percentage distribution of the different sized particles was curiously similar in all the samples, and it may be assumed that approximately half of all dust particles, that are countable by the method here employed, are about 1 micron in greatest diameter, the others ranging up to about 40 microns.
7. Dust removal at the point of production not only greatly decreases air dustiness, but particularly removes the smaller particles.

8. The substitution of wet processes for dry ones effectively lessens air dustiness.

9. Air dustiness varies inversely with relative atmospheric humidity, as does also the percentage of the larger dust particles.

\section{Clinical Notes, Suggestions, and New Instruments}

\section{AN UNUSUALLY LARGE VESICAL CALCULUS}

H. M. McCandliss, M.D., and Nathaniel Bercovitz, M.D., Hoi How, Hainan, China

Oct. 30, 1917, a man aged 31, entered the hospital complaining of great pain on urination, with pain over the bladder. The patient had been in this condition for over ten years, gradually getting worse. When he came to the hospital, he could not stand erect on account of the pain.

The man was emaciated, and his face and body were covered with pit marks of old smallpox. A sound introduced into the urethra met at the neck of the bladder a solid, immovable body. This could be palpated 2 inches above the pubes. The urine showed an intense cystitis. An incision

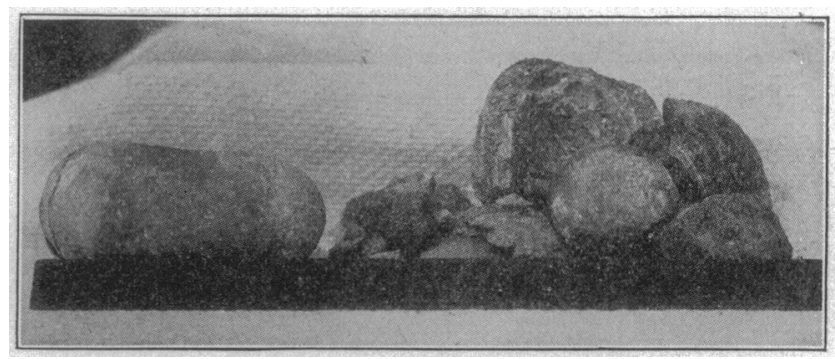

Fragments of calculus.

was made above the pubes almost to the urbilicus and the bladder, which was distended with boric acid solution and opened. A large irregular stone was disclosed which was found to be impacted. Efforts to dislodge it proved fruitless, and finally a hammer and chisel were used to break it into fragments.

An outer shell from three-fourths to seven-eighths inch in thickness was first broken through anteriorly and removed. The nucleus of the stone, 2 inches long, $1 \frac{1}{2}$ inches wide, and 1 inch thick, was then removed. The posterior portion of the shell was now dislodged and removed. A mass of small fragments and débris was removed, and the bladder thoroughy irrigated, although a considerable amount of "sand" was adherent to the walls of the bladder and the edges of the wound. A catheter was introduced, and a large rubber tube drain left in the suprapubic opening, the incision being closed in the usual manner.

After thorough drying, the fragments that were recovered weighed $385 \mathrm{gm}$. It was found impossible to reconstruct the stone, but the accompanying illustration of the fragments gives an idea of its size.

The postoperative history has been uneventful, and at the date of writing (November 21), the suprapubic opening is almost closed. How many stones heavier than this one have been reported?

American Presbyterian Hospital.

Great Nations.-The greatness of a nation is to be judged by the number of the great men it has produced.-Keen. 